ŁUKASZ Mirocha

Wałcz

\title{
LIBERALNE I KOMUNITARYSTYCZNE PRÓBY UZASADNIENIA WOLNOŚCI RELIGIJNEJ A ICH KONSEKWENCJE
}

\section{WstęP}

W nauce prawa prezentowane było stanowisko głoszące, że wolność religijna, historycznie rzecz biorąc, jest „prototypem” wszystkich pozostałych praw człowieka ${ }^{1}$. Nie może więc dziwić ugruntowany status wolności religijnej w dokumentach międzynarodowego prawa praw człowieka. Wolność ta znajduje bardzo mocne oparcie pozytywnoprawne, występując obok wolności sumienia i myśli². Pozycja wolności religijnej

1 Np. J. Habermas (Tolerancja religijna jako stymulator praw kulturowych, [w:] Między naturalizmem a religią. Rozprawy filozoficzne, przeł. M. PAŃkow, Warszawa 2012, s. 218) odnoszący się do J. Jellinka (Deklaracja praw człowieka i obywatela, przeł. Z. LibKind-LubodzieckA, Warszawa 1905, m.in. s. 8). W tym samym tonie pisze Jan PAweŁ II w encyklice Centesimus Annus z 1991 r., stwierdzając, że: „Źródłem i syntezą tych praw jest w pewnym sensie wolność religijna, rozumiana jako prawo do życia w prawdzie własnej wiary i zgodnie z transcendentną godnością własnej osoby" (\$ 47 encykliki). B. Leiter (Why Tolerate Religion?, «Constitutional Commentary» 25.1/2008, s. 1) uważa, że tolerancja religijna jest paradygmatyczna dla liberalnej idei tolerancji względem odmienności grupowych.

2 W kwestiach terminologicznych por. W. Soвczak, Wolność myśli, sumienia i religii. Poszukiwanie standardu europejskiego, Toruń 2013, s. 38-57. W pracy intencjonalnie 
jako specjalnego prawa jest jednak coraz częściej negowana. Wskazywane są problemy z jej uzasadnieniem. Wynikać mają one zasadniczo z braku możliwości przypisania religii przekonującej differentia specifica $\mathrm{w}$ konfrontacji z innymi, niereligijnymi poglądami ${ }^{3}$, przy jednoczesnym zachowaniu szczególnego statusu i uprawnień z niej wypływających, niegwarantowanych tym poglądom.

W artykule podejmuję próbę odtworzenia i oceny uzasadnień wolności religijnej prezentowanych przez dwa przeciwstawne nurty współczesnej filozofii prawa. Wybór współczesnego liberalizmu i komunitaryzmu wynika z faktu, że filozofie te, w przeciwieństwie do innych nurtów zajmujących się często partykularnymi problemami, na przykład feminizmu czy multikulturalizmu, dotykają swoją wizją wszystkich sfer życia społecznego (w tym religii), są rozległe w rozumieniu Johna Rawlsa ${ }^{4}$. Analiza komunitarystycznego uzasadnienia może być szczególnie cenna, biorąc pod uwagę aktualną sytuację polityczną w Polsce - odwoływanie się rządzących do tego właśnie nurtu, łatwe do odczytania z częstych nawiązań do idei solidaryzmu społecznego lub patriotyzmu. W tym kontekście warto wspomnieć słowa Jolanty Zdybel, która pisząc o jednym z czołowych przedstawicieli komunitaryzmu, stwierdziła, że „o ile zarzuty stawiane MacIntyre'owi bazują tylko na wyobrażeniach, o tyle

posługuję się sformułowaniem „wolność religijna” jako tłumaczeniem używanego w literaturze anglosaskiej religious freedom, a nie pojęciem „wolność religii”, obecnym w polskich tłumaczeniach dokumentów międzynarodowego prawa praw człowieka.

3 Por. np. W.P. Marshall, Smith, Christian Legal Society, and Speech-Based Claims for Religious Exemptions From Neutral Laws of General Applicability, «Cardozo Law Review» 32/2010-2011, s. 1937-1939; S.D. SмIтн, The Rise and The Fall of Religious Freedom in Constitutional Discourse, «University of Pennsylvania Law Review» 140/1990-1991, s. 151, 219, 225; B. LeITER, op. cit., s. 2, 12, 26 i n.; warto przypomnieć, że religioznawcy również wskazują na problem z wypracowaniem satysfakcjonującej definicji religii, por. J. Keller, Religia, [w:] Zarys dziejów religii, red. J. Keller, W. Kotański, W. Tyloch, B. KuPIs, Warszawa 1986, s. 5-6.

4 J. Rawls (Liberalizm polityczny, przeł. A. Romaniuk, Warszawa 1998, s. 48) uznaje swoją koncepcję liberalizmu za nierozległą, bowiem ma ona dotykać tylko sfery politycznej, z czym można polemizować. 
fatalne skutki liberalizmu są namacalne"s. Obecna sytuacja pozwala na weryfikację prawdziwości zarzutów stawianych komunitarystom. Parafrazując słynne rozróżnienie na „prawo w książkach” i „prawo w działaniu" (law in books and law in action), można stwierdzić, że jesteśmy obserwatorami komunitaryzmu w działaniu.

W opracowaniu nie rekonstruuję podstaw komentowanych nurtów w zakresie wykraczającym poza interesującą mnie kwestię uzasadnienia wolności religijnej6. Tytułowe „konsekwencje” ilustruję przykładami rozstrzygnięć z wokandy Europejskiego Trybunału Praw Człowieka w Strasburgu (dalej: ETPC lub Trybunał), Sądu Najwyższego Stanów Zjednoczonych oraz polskiego Trybunału Konstytucyjnego. Już w tym miejscu należy zastrzec, że podobne rozwiązania - chociaż z różnych powodów - będą często znajdowały wsparcie w obydwu nurtach filozofii prawa.

\section{Problemy liberalizmu Z UZASAdNieniem WOLNośCi RELIGIJNEJ}

Szkicując obraz liberalnego podejścia do wolności religijnej, posłużę się wywodem Ronalda Dworkina z jego ostatniej pracy?. Argumentacja autora Biorac prawa poważnie jest moim zdaniem reprezentatywna dla współczesnego liberalizmu zorientowanego na prawa (rights-oriented liberalism), wpisuje się w nurt krytyczny względem szczególnego statusu wolności religijnej.

Dworkin stwierdza, że religia jest pojęciem interpretacyjnym, zatem ,jego użytkownicy nie zgadzają się co do jego ścisłego znaczenia:

5 J. Zdy BEL, Między wolnością a powinnością. Filozofia polityczna Isaiaha Berlina i Alasdaira MacIntyre'a, Lublin 2005, s. 397, 405.

6 Spór liberałów i komunitarystów jest zagadnieniem bardzo dobrze opracowanym również w polskiej literaturze, por. np. A. SzAHAJ, Jednostka czy wspólnota? Spór liberałów z komunitarystami a „sprawa polska”, Warszawa 2000; L. MoRAwsKI, Główne problemy współczesnej filozofii prawa. Prawo w toku przemian, Warszawa 2005, s. 167-196.

7 R. Dworkin, Religia bez Boga, przeł. B. BAran, Warszawa 2014. 
używając go zajmują stanowisko w kwestii, co pojęcie to powinno

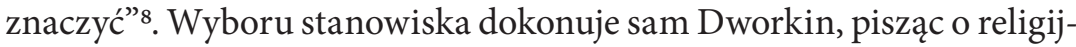
nym ateizmie i budując swoją definicję religii przy rezygnacji z elementu związku człowieka czy społeczności z sacrum. Zdaniem amerykańskiego filozofa by można było mówić o postawie religijnej, człowiek powinien móc podpisać się pod dwoma twierdzeniami. Pierwsze głosi, że ludzkie życie ma obiektywną wartość, zatem każdy jest odpowiedzialny za uczynienie swojego życia udanym, przyzwoitym. Chodzi więc o inherentną ważność życia ludzkiego. Dworkin akcentuje dalej prawo do realizowania przez każdego własnej koncepcji dobrego życia, która wynika z tej wartości ${ }^{9}$. Drugie twierdzenie to uznanie „wzniosłości” przyrody, uznanie jej ważności. Obydwie wartości są dla człowieka religijnego (w rozumieniu amerykańskiego filozofa) niedyskutowalne, niewymagające uzasadnienia i realne „jak drzewo czy ból”"10. Jak zauważa Jeremy Waldron, przyjęte przez Dworkina założenia prowadzą do uczynienia - przy rozstrzyganiu sporów etycznych - obiektywnych wartości (w domyśle dostępnych wszystkim obywatelom) pierwszymi względem tych czerpanych $\mathrm{z}$ religii teistycznych ${ }^{11}$.

Definicja proponowana przez Dworkina jest bardziej liberalna od klasycznych definicji religii, które zakładają, że elementem konstytutywnym dla poglądów religijnych jest relacja między osobą czy wspólnotą a sacrum ${ }^{12}$. Pojęcie sacrum oznacza przy tym nie tylko osobowego boga, lecz także inne formy świętości - świętą przestrzeń, święty czas, święte elementy przyrody ${ }^{13}$. W budowanej przez amerykańskiego filozofa definicji religii transcendencja przestaje być elementem przesądzającym.

\footnotetext{
$8 \quad$ Ibidem, s. 18.

$9 \quad$ Ibidem, s. 106.

$10 \quad$ Ibidem, s. 23.

11 J. Waldron, Religion without God by Ronald Dworkin - Review, «Boston University Law Review» 94.4/2014, s. 1208.

12 Por. J. Keller, op. cit., s. 6; K. Kościelniak, Chrześcijaństwo w spotkaniu z religiami świata: podstawy religiologii, prezentacja najważniejszych religii świata, wyraźnie ukazane różnice, uniwersalizm i wyjątkowy charakter chrześcijaństwa, problem sekt, wybór tekstów źródłowych z komentarzami, Kraków 2002, s. 13.

13 Por. M. Eliade, 'Sacrum' a 'profanum'. O istocie sfery religijnej, przeł. B. BARAN, Warszawa 2008, s. 21, który mówi również o „postawie kryptoreligijnej”, pokrywającej
} 
W ocenie Dworkina nie może ona być również wyróżnikiem praw gwarantowanych jedynie pewnej grupie społeczeństwa. Zasada niewyróżniania i równego traktowania przez państwo odgrywa istotną rolę w myśli Dworkina i reprezentowanego przez niego nurtu filozoficznego, także na płaszczyźnie wolności religijnej ${ }^{14}$. Jak się wydaje, stoi to u podstaw Dworkinowskiej reinterpretacji pojęcia religii.

Dworkin wskazuje, że jego definicja ma mieć charakter ekumeniczny - jest maksymalnie szeroka. Z drugiej strony, na tyle ścisły, by pozwoliła rozstrzygać coraz częściej pojawiające się w judykaturze wątpliwości odnośnie do tego, co podlega ochronie w myśl amerykańskiej free exercise clause czy art. 9 Konwencji o ochronie praw człowieka i podstawowych wolności (dalej: EKPC lub konwencja) ${ }^{15}$. Ma ona mieć walor pragmatyczny.

W dalszej części pracy Amerykanin dostrzega jednak problemy związane nawet $\mathrm{z}$ tak zaprojektowaną definicją religijności. Stawia on pytanie, czy homoseksualizm, monarchizm, materializm, a nawet rasizm, nie będą podpadały pod nakreśloną wcześniej definicję, a jeśli tak, to czy na pewno należy im się $\mathrm{z}$ tego tytułu ochrona ${ }^{16}$. Spełniają one co najmniej pierwszy ze sformułowanych przez Dworkina warunków postawy religijnej ${ }^{17}$. Pojawiają się także kolejne wątpliwości dotyczące samej tradycyjnie rozumianej - wolności religijnej. Poza brakiem możliwości przekonującego zdefiniowania religii, ujawnia się wewnętrzna sprzeczność tego prawa. Wolność religijna zabrania dyskryminowania - nierównego traktowania różnych wyznań (co wynika raczej z amerykańskiej

się częściowo z definicją Dworkina, bowiem obejmuje nawet tzw. substytuty religii, np. religie obywatelskie.

14 Por. C. LABORDE, Dworkin's Freedom of Religion without God, «Boston University Law Review» 94.4/2014, s. 1256-1257, 1260.

15 Problem $\mathrm{z}$ delimitacją pojęcia religii obrazują między innymi orzeczenia dotyczące przedsięwzięć scjentologów, por. decyzję Europejskiej Komisji Praw Człowieka z 5 maja 1979 r. w sprawie X i Kościół Scjentologiczny p. Szwecji, nr skargi 7805/77.

16 R. DWORKIN, op. cit., s. 106-110.

17 Być może spełniłyby też niektóre z wymienionych przez Eliade’a. 
no establishment clause), każe jednak udzielać „dyspensy” przedstawicielom niektórych $\mathrm{z}$ nich w pewnych dziedzinach ${ }^{18}$.

Poparciem spostrzeżeń amerykańskiego klasyka możne być sprawa Kokkinakis p. Grecji rozstrzygnięta przez ETPC ${ }^{19}$. Skarżący, świadek Jehowy, domagał się stwierdzenia naruszenia wolności religijnej przez greckie władze, które skazały go za przestępstwo prozelityzmu, gdyż wykonując religijny obowiązek, nakłaniał rzekomo pokrzywdzoną do zmiany wyznania. Władze argumentowały, że penalizacja prozelityzmu ma właśnie chronić wolność religijną potencjalnych ofiar ${ }^{20}$. Zarówno skarżący, jak i jego ofiara mogli wywodzić pożądane dla siebie skutki z komentowanego prawa, co może być traktowane jako jego wewnętrzna sprzecznośćc ${ }^{2}$. Trudno jednak nie dostrzec, że tak pojmowana wewnętrzna sprzeczność nie cechuje wyłącznie wolności religijnej, ale dotyka też innych praw.

Dworkin dochodzi do wniosku, że wolność religijna nie powinna korzystać ze statusu specjalnego prawa, jakim cieszy się obecnie. Wolność religijną należy interpretować jako (nieposiadający dostatecznego uzasadnienia) składnik wolności politycznej wraz z szerszym prawem do „niezależności etycznej”22. To ostatnie prawo nie przysługuje jedynie

18 R. DWORkin, op. cit., s. 118. S.D. Smith (op. cit., s. 225) podobnie diagnozuje skutki problemów z uzasadnieniem wolności religijnej - pierwszym jest niespójność orzecznicza, drugim odmowa uznania ochrony wynikającej z wolności religijnej, mimo że w analogicznych sytuacjach była udzielana (co w istocie sprowadza się do niespójności).

19 Wyrok ETPC z 25 maja 1993 r. w sprawie Kokkinakis p. Grecji, nr skargi 14307/88.

20 "The Government contended that a democratic State had to ensure the peaceful enjoyment of the personal freedoms of all those living on its territory. If, in particular, it was not vigilant to protect a person's religious beliefs and dignity from attempts to influence them by immoral and deceitful means, Article 9 para. 2 (art. 9-2) would in practice be rendered wholly nugatory." (\$ 42$)$.

21 Por. P.G. Danchin, Of Prophets and Proselytes: Freedom of Religion and the Conflict of Rights in International Law, «Harvard International Law Journal» 49.2/2008, s. 274 .

22 R. Dworkin, op. cit., s. 119. Podobnie sprawę przedstawia B. Leiter (op. cit., s. 6-7, 26-27), wskazując, że można znaleźć mocne racje na rzecz wolności sumienia, ale trudno jest uzasadnić jego zdaniem szczególną pozycję religii, pokazuje on, że do podobnych wniosków prowadzi analiza myśli J. Rawlsa oraz argumentów utylitarnych. 
zwolennikom poglądów teistycznych ani nawet osobom cechującym się postawą religijną w rozumieniu Dworkina. Przysługuje ono wszystkim i winno zastąpić wolność religijną. Podejście to jest brzemienne w skutki. Główną konsekwencją uznania prymatu niezależności etycznej kosztem wolności religijnej jest konieczność zapewnienia neutralności światopoglądowej państwa i ścisłego rozdziału Kościoła od państwa (liberalnie pojmowanych - abstrahuję tu od problemu neutralności samej neutralności). Państwo nie może, nie naruszając niezależności etycznej, powoływać się na racje inspirowane moralnie czy religijnie, co byłoby moim zdaniem możliwe, gdyby poprzestało na standardzie wolności religijnej, pojmowanej jako swoboda wykonywania praktyk religijnych i zakaz ingerencji państwa w sferę sumienia a nie określone rozwiązanie instytucjonalne. Interpretacja Dworkin kładzie większy nacisk na obecną w I poprawce do amerykańskiej Konstytucji klauzulę no establishment, niż trafniej oddającą istotę wolności religijnej klauzulę free exercise.

Dworkin, odwołując się do postulatu niezależności etycznej, wskazuje na rozwiązania odwrotne względem przyjętych na przykład przez ETPC. Pisze, że niedopuszczalne jest eksponowanie przez państwo symboli religijnych w „budynku sądu czy na publicznych ulicach”23. Problem ten był przedmiotem orzeczenia ETPC w sprawie Lautsi p. Włochom ${ }^{24}$, w którym strasburscy sędziowie uznali za zgodne z art. 9 konwencji eksponowanie krzyża w klasach włoskich szkół publicznych. Sąd Najwyższy USA wielokrotnie wypowiadał się w tej materii, wydając odmienne orzeczenia. Bywało jednak, że akceptował obecność symboli religijnych w sferze publicznej, jak w wyroku Salazar p. Buono z 28 kwietnia 2010 r.

Zgodnie z perspektywą amerykańskiego filozofa państwo nie może natomiast zabraniać noszenia religijnie motywowanych chust czy burek. W judykaturze strasburskiego Trybunału zakaz taki zyskuje aprobatę. Warto wspomnieć chociażby wyroki w sprawach Dahlab p. Szwajcarii, Sahin p. Turcji, Dogru p. Francji (dotyczyły one zakazu noszenia nakryć

23 R. DWORKIN, op. cit., s. 126.

24 Wyrok ETPC z 18 marca 2011 r., nr skargi 30814/06. Podkreślić trzeba, że na treść przywołanych w tekście wyroków ETPC znaczny wpływ miało odwołanie się przez strasburskich sędziów do doktryny marginesu uznania. 
głowy w szkołach publicznych) czy orzeczenie w sprawie S.A.S. p. Francji ${ }^{25}$, w którym ETPC zaakceptował bezwzględny zakaz noszenia chust we wszystkich miejscach publicznych.

Warto postawić pytanie, czy biorąc pod uwagę powyższe, trafna jest diagnoza stawiana przez Michaela Sandela, który stwierdza, że dla liberała wolność religijna jest tylko elementem wolności i autonomii pojmowanych ogólnie ${ }^{26}$. Według niego - przyjmując liberalną interpretację - trudne jest odróżnienie, które zachowania winny podlegać ochronie. Ilustrując tę tezę - rytualne konsumowanie pejotlu przez Indian czy również rekreacyjne, pozbawione głębszego znaczenia odurzanie się przez narkomana, ma korzystać z gwarancji ${ }^{27}$. Wskazać trzeba, że diagnoza ta nie jest do końca trafna w odniesieniu do konstrukcji proponowanej przez Dworkina. Autor Religii bez Boga, mimo że nie dostrzega silnych racji przemawiających za utrzymaniem wolności religijnej jako specyficznego prawa, wskazuje, że poza ochroną winny znajdować się na przykład takie poglądy jak materializm czy konsumpcjonizm ${ }^{28}$. Dokonuje więc wartościowania, którego brak zarzucają liberałom między innymi komunitaryści.

\section{KomUNITARYSTYCZNE PRÓBY UZASADNIENIA WOLNOŚCI RELIGIJNEJ}

Jaka jest odpowiedź komunitarystów na liberalne, odwołujące się do autonomii uzasadnienia wolności religijnej? Zacznijmy od Sandela, którego podejście trzeba określić mianem teleologicznego. Pierwszym

25 Wyrok ETPC z 1 lipca 2014 r., nr skargi 43835/11.

26 M.J. SANDEL, Liberalizm a granice sprawiedliwości, przeł. A. Grobler, Warszawa 2009, s. 29.

27 Ibidem, s. 29-30. Rytualne spożywanie przez Indian pejotlu było przedmiotem wyroku Sądu Najwyższego USA w sprawie Employment Division Department of Human Resources of Oregon p. Smith z 17 kwietnia 1990 r., w którym sąd uznał, że odmowa wypłaty zasiłku osobie, która została zwolniona z pracy z uwagi na konsumpcję nielegalnego pejotlu, nie narusza wolności religijnej.

28 R. DWORKIN, op. cit., s. 108 i n. 
krokiem, który stawia ten amerykański filozof, jest odróżnienie zobowiązań inspirowanych religijnie od tych wynikających z pospolitych preferencji czy interesów. Te ostatnie leżą w sferze wolnego wyboru jednostki, zaś przekonania religijne mogą znajdować się poza nią. Sandel podziela komunitarystyczną wizję „jaźni zakorzenionej” czy „osadzonej”, przyznając, że religia może być nieodłącznym składnikiem tożsamości człowieka ${ }^{29}$. Odwołując się do pochodzącego od Williama P. Marshalla rozróżnienia na religion as identity oraz religion as ideas ${ }^{30}$, stwierdzić trzeba, że Sandelowi bliższa jest ta pierwsza interpretacja religii. Idzie on jednak przy tym krok dalej. Jego zdaniem głównym i wspólnym dla liberalizmu i komunitaryzmu grzechem jest ucieczka przed ocenianiem postaw oraz poglądów, w tym religijnych. Drogą liberalnego eskapizmu jest neutralność światopoglądowa państwa, komunitaryzm gloryfikuje natomiast tradycję i wspólnotę, zamiast podjąć próbę oceny słuszności wspieranych przez nie poglądów. Stanowisko Sandela oddaje cytat: „Przyznanie szczególnej ochrony swobodzie praktyk religijnych jest dobrze uzasadnione przy założeniu, że wiara, praktykowana w charakterystyczny dla danej społeczności sposób, kształtuje godne najwyższej oceny postawy życiowe i zasady postępowania - albo dlatego, że są chwalebne same przez się, albo dlatego, że rozwija cechy charakteru właściwe dobrym obywatelom"31.

Komunitarysta buduje uzasadnienie wolności religijnej, traktując religię jako inkubator cnót obywatelskich ${ }^{32}$. Pełnienie tej funkcji może być racją za przyznaniem religii szczególnej ochrony, w przeciwnym wypadku ta nie przysługuje. Logiką zbliżoną do przedstawionej przez Sandela kierował się ETPC w sprawach chust muzułmańskich, gdy odmawiając ochrony noszącym je kobietom, oceniał islam jako religię

29 M.J. SANDEL, Liberalizm a granice sprawiedliwości..., s. 29.

30 W.P. MARShall, op. cit., s. 1939.

31 M.J. SANDEL, Liberalizm a granice sprawiedliwości..., s. 31; warto przypomnieć, że Locke w Liście o tolerancji odmawiał wolności religijnej katolikom, twierdząc, iż będą służyli obcemu państwu oraz ateistom, utrzymując, że nie posiadając „wyższej instancji”, mogą okazać się wiarołomcami - dokonywał więc swoistej oceny praktyk religijnych.

32 Por. S.D. Smith, op. cit., s. 199-202. 
między innymi promującą nierówność płci ${ }^{33}$. Opinię tę można traktować jako opartą bardziej na stereotypach niż rzetelnej analizie, jednak postępowanie Trybunału w tym zakresie ilustruje odejście od neutralności i próbę oceny substancjalnej, postulowanej przez Sandela. Rozumowanie zbliżone do teleologicznego, ETPC przedstawił również w sprawach dotyczących bluźnierstwa, wskazując, że działania skarżących - najczęściej kontrowersyjnych artystów - nie zasługują na ochronę, gdyż nie wpisują się w postulat realizacji wartości konwencyjnych, takich jak pluralizm, otwartość czy tolerancja ${ }^{34}$. Jako jeszcze trafniejszy przykład teleologizmu - choć nadal niekoniecznie zbieżny z ewentualną oceną Sandela - można potraktować wypowiedź polskiego Trybunału Konstytucyjnego zawartą w wyroku z 28 maja 1997 r. (K 26/96). Czytamy w nim, że pojęcie rodziny „zakłada ochronę pewnej skomplikowanej rzeczywistości społecznej będącej sumą stosunków łączących przede

33 "The Court stressed the "powerful external symbol" represented by wearing the headscarf and also considered the proselytising effect that it might have seeing that it appeared to be imposed on women by a religious precept which was hard to square with the principle of gender equality" (wyrok ETPC z 4 grudnia 2008 r. w sprawie Dogru p. Francji, nr skargi 27058/05, \$64); „In such a context, where the values of pluralism, respect for the rights of others and, in particular, equality before the law of men and women are being taught and applied in practice, it is understandable that the relevant authorities should wish to preserve the secular nature of the institution concerned and so consider it contrary to such values to allow religious attire, including, as in the present case, the Islamic headscarf, to be worn" (wyrok ETPC z 10 listopada 2005 r. w sprawie Leyla Sahin p. Turcji, nr skargi 44774/98, § 116).

${ }_{34}$ „Such are the demands of that pluralism, tolerance and broadmindedness without which there is no "democratic society" (see, particularly, the Handyside v. the United Kingdom judgment of 7 December 1976, Series A no. 24, p. 23, para. 49). However, as is borne out by the wording itself of Article 10 para. 2 (art. 10-2), whoever exercises the rights and freedoms enshrined in the first paragraph of that Article (art. 10-1) undertakes "duties and responsibilities". Amongst them - in the context of religious opinions and beliefs - may legitimately be included an obligation to avoid as far as possible expressions that are gratuitously offensive to others and thus an infringement of their rights, and which therefore do not contribute to any form of public debate capable of furthering progress in human affairs" (wyrok ETPC z 20 września 1994 r. w sprawie Otto Preminger Institut p. Austrii, nr skargi 13470/87, \$49); por. również wyrok ETPC w sprawie Wingrove p. Zjednoczonemu Królestwu z 25 listopada 1996 r., nr skargi 17419/90. 
wszystkim rodziców i dzieci”, zaś podstawową funkcją rodziny jest funkcja prokreacyjna ${ }^{35}$. Komentarz tej treści nie pozostawia wątpliwości, że polski Trybunał szukał podstawy dla poglądu, że rodzina zasługuje na szczególną ochronę, rozważał, jaki jest cel określający jej istotę ${ }^{36}$. Liberalny tok rozumowania przebiegałby inaczej - skoro dwójka ludzi może, korzystając z wolności wyboru, chcieć zbudować związek, należy im to umożliwić i objąć go ochroną.

Propozycji Sandela postawić można co najmniej dwa zarzuty. Pierwszy z nich wyraża się w pytaniu, „czy podejście teleologiczne np. do wolności religijnej, nie jest wyrazem instrumentalnego traktowania religii?”. Drugi zarzut można sformułować w następujący sposób. Jeśli uznajemy za decydujące dla objęcia ochroną znaczenie okoliczności, czy dana praktyka, pogląd, postawa służą społeczeństwu, to nie powinniśmy chronić w szczególny sposób również pozareligijnych praktyk, poglądów itp., pod warunkiem że spełniają one to kryterium. Zbliżałoby to nas do podejścia prezentowanego przez Dworkina.

Pierwszy zarzut jest tylko częściowo trafny. Przypomnijmy, że Alasdair MacIntyre, wykładając swoją teorię cnót, wskazywał, iż stanowią one wartość samą w sobie (inherentną), ale są również niezbędne dla poszukiwania naszego dobra (wartość instrumentalna) ${ }^{37}$. Religijność jest cnotą zarówno u MacIntyre’a, jak i Sandela. Obu łączy pogląd, że cel danej praktyki czy instytucji jest w nią wpisany (co nie znaczy, że nie może się zmieniać), a korzystając z cnót, raczej go odkrywamy (jak zrobił to polski TK), niż im go nadajemy. W tym sensie religijność pozwala odkrywać telos czy dobro przynależne życiu społecznemu, które współtworzy. Holistyczne podejście komunitarystów dezaktualizuje

35 K. Complak (Komentarz do art. 18 Konstytucji Rzeczypospolitej Polskiej, [dostęp: Lex Omega]) pisze, że „takie stanowisko zderza się [...] z poglądem Europejskiego Trybunału Praw Człowieka”, który przyjmuje, że dla zaistnienia rodziny wystarczy para, zaś istnienie potomstwa nie należy do jej cech konstytutywnych - orzeczenie ETPC z 11 lipca 2002 r. w sprawie Cristine Goodwin v. Wielka Brytania (nr skargi 28957/95).

36 Por. stanowisko M.J. SANdela (Sprawiedliwość. Jak postępować słusznie?, przeł. O. Siara, Warszawa 2013, s. 341-351) odnośnie do małżeństw jednopłciowych.

37 W. Kymlicka (Współczesna filozofia polityczna, przeł. A. PAWELEC, Warszawa 2009, s. 347-387) wskazuje, że instrumentalne znaczenie cnót zaczynają akceptować nawet liberałowie, komunitaryści i republikanie z kolei uznają ich inherentną wartość. 
więc zarzut, że religia służy celowi zewnętrznemu i jest instrumentalnie wykorzystana.

Odnosząc się do drugiego zarzutu, trzeba dotknąć wspomnianego już, „klasycznie” wspólnotowego uzasadnienia wolności religijnej. Można je wyjaśnić, odwołując się do narracyjnej koncepcji jednostki MacIntyre’a czy innych komunitarystycznych ujęć jednostki zakorzenionej. Zdaniem komunitarystów pewne zobowiązania mają konstytutywne dla tożsamości jednostki znaczenie. Są one niezależne od naszych wyborów. Wynikają one z osadzenia nas w określonym środowisku społecznym, pozostawania czyimś synem, córką, ojcem, członkiem wspólnoty lokalnej, wyznaniowej, państwowej, jak obrazowo pisał szkocki myśliciel ${ }^{38}$. Europejski Trybunał Praw Człowieka zbliżył się do tego poglądu na przykład w wyroku ze sprawy Kokkinakis p. Grecji, stwierdzając, że religia jest żywotnym elementem tożsamości wierzących $^{39}$. Tak wygląda, zdaniem MacIntyre’a, właściwy obraz jednostki, w przeciwieństwie do poglądu woluntarystycznego, który przedstawił Rawls w Teorii sprawiedliwości. Osadzenie nas w pewnych praktykach (także religijnych) określa naszą tożsamość, jaźń, osobowość, czy tego chcemy, czy nie. Co więcej, osadzenie w tych praktykach czy szerzej we wspólnocie - dostarcza nam języka moralnego niezbędnego do porozumiewania się z pozostałymi członkami wspólnoty. Bez niego skazani bylibyśmy (a zdaniem MacIntyre’a jako ofiary nowoczesności i liberalizmu - jesteśmy) na los budowniczych wieży Babel. Religia odgrywa szczególną rolę w zaopatrywaniu nas w środki moralnego wyrazu. Warto przy tym zauważyć, że odbywa się to niezależnie od postępującej pluralizacji i obumierania substancjalnego konsensu w społeczeństwach. Nawet niewierzący rozumieją i posługują się pojęciami o religijnym rodowodzie, jak grzech czy miłosierdzie.

38 A. Macintyre, Dziedzictwo cnoty: studium z teorii moralności, przeł. A. ChmieLEWSKI, Warszawa 1996, s. 392.

39 "It is, in its religious dimension, one of the most vital elements that go to make up the identity of believers and their conception of life, but it is also a precious asset for atheists, agnostics, sceptics and the unconcerned" (wyrok ETPC z 25 maja 1993 r. w sprawie Kokkinakis p. Grecji, nr skargi 14307/88, \$ 31). 
Teraz jasne staje się, że drugi z rozważanych zarzutów jest nieuzasadniony, ponieważ koncentruje się jedynie na wtórnym warunku objęcia określonych praktyk ochroną, tj. ich celowości, pomija natomiast kwestię konstytutywnej dla tożsamości człowieka roli religii. Przykładowo wolontariat może być praktyką, która buduje godne pochwały postawy, ale niekoniecznie musi określać czyjąś jaźń czy być spójnikiem wspólnoty. Z drugiej strony, bycie kibicem piłkarskim może być częścią czyjejś tożsamości, ale niekoniecznie praktyka ta przejdzie pomyślnie test teleologiczny. Połączenie argumentacji teleologicznej oraz traktującej religię jako składnik tożsamości człowieka pozwala moim zdaniem na obronę wolności religijnej jako specyficznego prawa. Strategia łączenia różnych linii uzasadnienia wydaje się najbardziej przekonująca ${ }^{40}$.

Interesujące, że John Rawls w Liberalizmie politycznym, rezygnując z kantowskiej wizji podmiotu, jako jeden z motywów dla poparcia wolności sumienia (co symptomatyczne - nie wolności religijnej) podaje, że koncepcje dobra mogą być "dane i mocno zakorzenione" 41 . Co więcej, odrzuca on wytykaną liberałom przez Sandela skłonność do traktowania wymogów sumienia na równi z pospolitymi preferencjami czy interesami ${ }^{42}$. Z tych przesłanek Rawls wyprowadza jednak inne wnioski niż komunitaryści. Argumentuje on, że skoro koncepcje dobra są „dane i zakorzenione”, a zatem nienegocjowalne, wszyscy powinni się zgodzić na zasady sprawiedliwości gwarantujące równą wolność sumienia. Taką równość zapewnia jego zdaniem sztywne oddzielenie sfery prywatnej i politycznej oraz filtr uniemożliwiający przenikanie racji opartych na koncepcji dobra poza sferę prywatną (można być komunitarystą w domu, ale na forum publicznym już nie, jak streścił to Will Kymlicka ${ }^{43}$ ). Wprowadzenie tego dualizmu nie jest wcale neutralne i niewiele ma wspólnego $\mathrm{z}$ równością ${ }^{44}$. Poza tym nie jest konieczne do zapewnienia wolności sumienia, pod warunkiem że nie utożsamiamy jej z „niezależnością etyczną”. Sandel drąży tę kwestię, pytając

\footnotetext{
40 Por. W.P. Marshall, op. cit., s. 1952.

41 J. Rawls, op. cit., s. 421.

42 Ibidem, s. 418.

43 W. Kymlicka, op. cit., s. 290.

44 J. Habermas, op. cit., s. 122.
} 
dlaczego obywatelom (czyli już nie jednostkom w sytuacji pierwotnej) miałoby zależeć na takim dualizmie. W odpowiedzi Rawls wskazywał, że demokratyczne społeczeństwa nowoczesne zaakceptowały już taki stan rzeczy ${ }^{45}$. Jako falsyfikację tej tezy można potraktować chociażby wyniki wyborów w kolejnych europejskich państwach, gdzie do głosu dochodzą ruchy nieliberalne. (Opór przed wzięciem w nawias własnych przekonań na potrzeby doraźnie przybranej roli zaobserwował także każdy wykładowca, który próbował przeprowadzić ze studentami akademicką dyskusję, narzucając im stanowisko sprzeczne z ich poglądami). Moim zdaniem wymóg pozostawienia własnej koncepcji dobra przed wejściem do sfery publicznej sprawia, że Rawlsowska sytuacja pierwotna przestaje być hipotetycznym modelem, zaczyna zaś pełnić rolę wzoru funkcjonowania tej sfery w rzeczywistości.

Komunitaryzm odrzuca dualizm jaźni, postuluje otwarcie sfery publicznej na religijnie inspirowaną argumentację (w radykalniejszej wersji zniesienie podziału na sferę prywatną i publiczną). Amerykańscy autorzy dokumentują ten postulat wieloma przykładami, gdy religijna motywacja stała u podstaw doniosłych zmian społecznych. Ilustracji tego zjawiska dostarcza również polska historia, vide udział Kościoła w obaleniu komunizmu czy utrzymaniu polskości w czasach zaborów. Komunitaryści, odwołując się do ideału inkluzywności, wskazują, że racje religijne mogą wzbogacić dyskurs publiczny, społeczeństwo może na tym tylko skorzystać ${ }^{46}$. Krytykując koncepcję neutralności, wskazują, że nie jest ona wcale neutralna; podają przykłady, gdy za frazeologią neutralności kryją się koniec końców substancjalne sądy (nie można rozstrzygnąć kwestii sprawiedliwości bez rozstrzygania istotnych dylematów moralnych ${ }^{47}$ ), argumentują, że nawet gdy zachowanie neutralności byłoby możliwe, nie musi być pożądane ${ }^{48}$.

45 M.J. SANDEL, Liberalizm a granice sprawiedliwości..., s. 287.

46 Por. A. Gutmann, Religious Freedom and Civic Responsibility, «Washington and Lee Law Review» 56/1999, s. 912; G.P. MAGARIAn, Religious Argument, Free Speech Theory, and Democratic Dynamism, «Notre Dame Law Review» 86.1/2011, s. 165.

47 J. Gray, Dwie twarze liberalizmu, przeł. P. RyMARCZy K, Warszawa 2001, zwłaszcza s. 34 .

48 M.J. Sandel, Sprawiedliwość..., s. 338. 
Taką wizję komunitaryzmu należy jednak skonfrontować z rzeczywistością głęboko spluralizowanych społeczeństw doby ponowoczesnej, w których odwołanie się przez państwo do twardych, substancjalnych ocen moralnych może raczej prowadzić do konfliktów niż budowania wspólnoty. Nie można wreszcie zapominać o wyrażonej przez Isaiaha Berlina przestrodze na temat ryzyka związanego ze stawianiem państwa w roli arbitra odnośnie do tego, co jest dla człowieka rzeczywiście czy prawdziwie dobre ${ }^{49}$.

\section{Konkluzje}

Podsumowując, stwierdzić trzeba, że liberalne i komunitarystyczne oblicza wolności religijnej zdecydowanie się od siebie różnią. Dla liberała wolność religijna ma źródło w autonomii jednostki, jest jedynie składnikiem szerzej pojmowanej wolności. Wynika to z faktu, że liberałowie kwestionują na ogół posiadanie przez jednostkę uprzednich względem jej wyborów celów czy zobowiązań (w tym kontekście Dworkin i Rawls są raczej wyjątkami). Argumentacja na rzecz wolności religijnej przebiega od wolności pojmowanej ogólnie do religii. Można ją zastosować do każdego innego interesu czy poglądu, uzasadnienia ochrony każdej instytucji, jeśli nakazuje to poszanowanie autonomii jednostki. Przy określaniu zakresu wolności nie możemy odwoływać się do żadnych zewnętrznych kryteriów, dokonywać oceny, przynajmniej do momentu, w którym naruszeniu ulegałaby analogiczna wolność drugiej osoby. Liberałom bliższa jest wizja „religii z wyboru” niż „religii z urodzenia”. Wiara nie zajmuje w liberalnym państwie jakiegoś szczególnego miejsca, religia nie pełni w koncepcjach współczesnych liberałów szczególnych funkcji społecznych. Obawa przed tym, że państwo ujawniające w jakiejkolwiek formie swoje związki z konkretnym wyznaniem zacznie narzucać obywatelom do niego nienależącym przekonania, nakazuje

49 Por. I. Berlin, Dwie koncepcje wolności, [w:] Cztery eseje o wolności, przeł. H. Bartoszewicz, D. Grinberg, D. Lachowska, A. Tanalska-Dulęba, Warszawa 1994, s. 194 i n. 
przerwanie wszelkich więzów państwo-Kościół. Znaczącą rolę w wywodach na rzecz rozdziału i neutralności odgrywa zatem argument $z$ równi pochyłej.

Inaczej prezentuje się komunitarystyczne oblicze wolności religijnej. Jej uzasadnienie przebiega odwrotnie niż u liberałów - od religii w kierunku wolności. Komunitaryści twierdzą, że najpierw należy ustalić, czy potencjalny przedmiot ochrony jest wartościowy, dopiero następnie zdecydować o tym, czy na nią zasługuje. W oczach komunitarystów religia na ogół zdaje ten test. Stanowi ona czynnik konstytuujący jaźń członków społeczeństwa, wielu ludzi nie potrafi bowiem oddzielić „siebie” od swoich religijnych przekonań. Bliska MacIntyre’owi, Sandelowi czy Walzerowi wydaje się koncepcja „religii z urodzenia” ${ }^{50}$. Religia może być czynnikiem spajającym społeczeństwo, promującym cenne wartości moralne, a nawet cnoty publiczne. Terry Eagleton pisze: „Żadna forma symboliczna w historii nie uzyskała zdolności religii do powiązania najwyższych prawd z powszednim bytowaniem niezliczonych rzesz ludzkich"51. Sens tej wypowiedzi jest bardzo komunitariański. Według komunitarystów państwo jest uprawnione do promowania określonego ideału moralnego, zatem może zajmować pozycję również w kwestiach religijnych, jeśli uważa, że jest to pożądane z punktu widzenia tego ideału. (Wyraźnie widać to na przykładzie polityki aktualnych polskich władz, np. w kontekście wracającego sporu aborcyjnego). Dla nowoczesnych komunitarystów nie oznacza to koniecznie prowadzenia polityki asymilacji, którą wcielały wcześniej w życie państwa narodowe. Poszanowanie wolności religijnej wiąże się z ideałem inkluzywności, czyli włączania do dyskusji ludzi prezentujących różne racje, tak by możliwe było decydowanie o słuszności różnych rozwiązań przy przyjęciu maksymalnie szerokiej perspektywy, nie zaś moralnej próżni. Ograniczeniem pola dyskusji nie jest neutralność, czyli abstrahowanie od poglądów na dobro, mogą nim natomiast być substancjalne oceny określonych poglądów. Wolność religijna w komunitarystycznym wyda-

50 M. Walzer, Polityka i namiętność. O bardziej egalitarny liberalizm, przeł. H. JANKowsKa, Warszawa 2006, s. 16 i n.

51 T. Eagleton, Kultura a śmierć Boga, przeł. B. Baran, Warszawa 2014, s. 123-124. 
niu może wreszcie przybierać kształt prawa kolektywnego, przysługiwać wspólnotom, nie zaś wyłącznie jednostkom, na co wskazywał między innymi Joseph Weiler ${ }^{52}$.

Tym, co łączy obydwa komentowane typy uzasadnień wolności religijnej, jest poleganie na uzasadnieniach świeckich. Ani liberałowie, ani komunitaryści nie odwołują się do twierdzeń o priorytecie czy szczególnej wrażliwości dóbr religijnych ${ }^{53}$, co oznacza akceptację tezy głoszącej, że uzasadnienie regulacji powszechnie obowiązujących powinno być powszechnie zrozumiałe.

\section{LIBERALNE I KOMUNITARYSTYCZNE PRÓBY UZASADNIENIA WOLNOŚCI RELIGIJNEJ A ICH KONSEKWENCJE}

\section{Streszczenie}

W nauce prawa prezentowane było stanowisko głoszące, że wolność religijna, historycznie rzecz biorąc, jest „prototypem” wszystkich pozostałych praw człowieka. Nie może więc dziwić ugruntowany status wolności religijnej w dokumentach międzynarodowego prawa praw człowieka. Wolność ta znajduje bardzo mocne oparcie pozytywnoprawne, występując obok wolności sumienia i myśli. Pozycja wolności religijnej jako specjalnego prawa jest jednak coraz częściej negowana. Wskazywane są problemy z jej uzasadnieniem. Wynikać mają one zasadniczo z braku możliwości przypisania religii przekonującej differentia specifica w konfrontacji z innymi, niereligijnymi poglądami, przy jednoczesnym zachowaniu szczególnego statusu i uprawnień z niej wypływających, niegwarantowanych tym poglądom. W artykule podejmuję próbę odtworzenia i oceny uzasadnień wolności religijnej prezentowanych przez dwa przeciwstawne nurty współczesnej filozofii prawa - liberalizm i komunitaryzm.

52 J.H.H. Weiler, Państwo i Naród, kościół, meczet, synagoga. Nieunikniona debata, przeł. J. Siudyka, «Forum Prawnicze» 1(3)/2011, s. 38.

53 S.D. Smith, op. cit., s. 154 i n. 


\section{The Liberal and Communitarian Grounds of Religious FreEdom AND THEIR CONSEQUENCES}

\section{Summary}

Many legal scholars have claimed that historically religious freedom could be considered the "prototype" of all the other human rights. Thus it is not surprising that the well-established status of religious freedom is present in the international legal documents on human rights. Religious freedom has a very strong foundation in positive law, alongside freedom of conscience and freedom of thought. However, recently its status as a special right has been denied more and more often. This is mainly due to problems with establishing the grounds for its special status: it is hard to say what sets religion apart from other, non-religious views, while at the same time maintaining the special status and privileges of religion as against other views which are not guaranteed such privileges. This article attempts to reconstruct and analyse the grounds for religious freedom presented by two antithetical trends in the contemporary philosophy of law, viz. liberalism and communitarianism.

Słowa kluczowe: prawa człowieka; neutralność światopoglądowa państwa; relacje państwo-Kościół; wolność religii; Ronald Dworkin; Michael Sandel.

Keywords: human rights; neutrality of the state; state-church relations; freedom of religion; Ronald Dworkin; Michael Sandel.

\section{Literatura:}

Berlin I., Cztery eseje o wolności, przeł. H. Bartoszewicz, D. Grinberg, D. LachowsKa, A. Tanalska-DulęBA, Warszawa 1994.

Complak K., Komentarz do art. 18 Konstytucji Rzeczypospolitej Polskiej, «Lex Omega», dostęp 18 marca $2018 \mathrm{r}$.

Danchin P.G., Of Prophets and Proselytes: Freedom of Religion and the Conflict of Rights in International Law, "Harvard International Law Journal» 49.2/2008, s. 249-321.

Dworkin R., Religia bez Boga, przeł. B. BARAn, Warszawa 2014.

EAgleton T., Kultura a śmierć Boga, przeł. B. BARAN, Warszawa 2014. 
Eliade M., 'Sacrum' a 'profanum'. O istocie sfery religijnej, przeł. B. BARAN, Warszawa 2008.

Gray J., Dwie twarze liberalizmu, przeł. P. Rymarczyk, Warszawa 2001.

Gutmann A., Religious Freedom and Civic Responsibility, «Washington and Lee Law Review» 56/1999, s. 907-922.

Habermas J., Między naturalizmem a religią. Rozprawy filozoficzne, przeł.

M. PAŃкоw, Warszawa 2012.

Jellinek J., Deklaracja praw człowieka i obywatela, przeł. Z. LibKInd-LuboDZIECKA, Warszawa 1905.

Kościelniak K., Chrześcijaństwo $w$ spotkaniu z religiami świata: podstawy religiologii, prezentacja najważniejszych religii świata, wyraźnie ukazane różnice, uniwersalizm i wyjątkowy charakter chrześcijaństwa, problem sekt, wybór tekstów źródłowych z komentarzami, Kraków 2002.

Kymlicka W., Współczesna filozofia polityczna, przeł. A. PaWelec, Warszawa 2009.

LABORDE C., Dworkin's Freedom of Religion without God, «Boston University Law Review» 94.4/2014, s. 1255-1271.

LeIter B., Why Tolerate Religion?, «Constitutional Commentary» 25.1/2008.

Macintyre A., Dziedzictwo cnoty: studium z teorii moralności, przeł. A. Chmielewski, Warszawa 1996.

Magarian G.P., Religious Argument, Free Speech Theory, and Democratic Dynamism, «Notre Dame Law Review» 86.1/2011, s. 119-181.

Marshall W.P., Smith, Christian Legal Society, and Speech-Based Claims for Religious Exemptions From Neutral Laws of General Applicability, «Cardozo Law Review» 32/2010-2011, s. 1937-1958.

Rawls J., Liberalizm polityczny, przeł. A. Romaniuk, Warszawa 1998.

SANDEL M.J., Liberalizm a granice sprawiedliwości, przeł. A. Grobler, Warszawa 2009.

SAndel M.J., Sprawiedliwość. Jak postępować słusznie?, przeł. O. Siara, Warszawa 2013.

Smith S.D., The Rise and The Fall of Religious Freedom in Constitutional Discourse, «University of Pennsylvania Law Review» 140/1990-1991, s. 149-240.

Sobczak W., Wolność myśli, sumienia i religii. Poszukiwanie standardu europejskiego, Torun 2013.

WALDRON J., Religion without god by Ronald Dworkin - Review, «Boston University Law Review» 94.4/2014, s. 1207-1212.

Walzer M., Polityka i namiętność. O bardziej egalitarny liberalizm, przeł. H. JankowsKa, Warszawa 2006. 
Weiler J.H.H., Państwo i Naród, kościól, meczet, synagoga. Nieunikniona debata, przeł. J. SiUdy KA, «Forum Prawnicze» 1(3)/2011, s. 37-45.

Zarys dziejów religii, red. J. Keller, W. Kotański, W. Tyloch, B. Kupis, Warszawa 1986.

Zdy BeL J., Między wolnościa a powinnością. Filozofia polityczna Isaiaha Berlina i Alasdaira MacIntyre'a, Lublin 2005. 